\section{An Inexpensive Humidity Tent for Screening Plants against Disease}

\section{Dougal M. Russell}

Queensland Department of Primary Industries, Granite Belt Horticultural Research Station, P.O. Box 501, Stanthorpe, Queensland 4380, Australia

Additional index words. bacterial spot, Xanthomonas campestris pv. pruni, Japanese plum, Prunus salicina

Resistance to bacterial spot [Xanthomonas campestris pv. pruni (Smith) Dye] is a primary goal of our Japanese plum (Prunus salicina Lindel and hybrids) breeding project (Topp and Russell, 1989). Seedlings, raised in glasshouses between April and October, are potted onto double-layer benches and inoculated with bacterial spot at a height of 75 to $300 \mathrm{~mm}$. Inoculated seedlings require high humidity and temperatures between 13 and $30 \mathrm{C}$ for 4 weeks to establish the disease (Russell et al., 1991).

Conventional controlled-environment cabinets that hold 200 to 400 (0.52 liters, 10 $\mathrm{cm})$ pots are expensive (U.S. $\$ 12,000$ to $\$ 15,750)$. I have developed a low-cost plastic structure that provides a controlled-environment for 700 potted seedlings.

The facility is adapted to an existing glasshouse modified with a false ceiling of translucent plastic sheeting (Fabricon; Rheem Australia, Archerfield, Australia). This plastic sheeting is suspended on support wires above the ceiling to enlcose an area $2.7 \times$ $2.4 \times 2.1 \mathrm{~m}$ high (Fig. 1). This size is large enough for an inoculation bench, eliminating the need to transfer plants from an inoculation unit. The tent can be extended by hang-

Received for publication 12 Dec. 1991. Accepted for publication 27 Apr. 1992. Mention of a trade name, proprietary product, or vendor does not constitute a guarantee or warranty of the product by the author or the Queensland Dept. of Primary Industries and does not imply the approval to the exclusion of other vendors that may also be suitable. The cost of publishing this paper was defrayed in part by the payment of page charges. Under postal regulations, this paper therefore must be hereby marked advetisement solely to indicate this fact. ing extra sheeting on the wires, enclosing four benches instead of two. Seedlings are grown on mobile, double-layered benches 2.4 $\times 0.75 \times 1.2$ high. A simple zipper sown into the sheeting provides a doorway to wheel in the double benches of plants. Existing bar heaters, combined with a Defensor 505 (Defensor AG, Pfäffikon, Switzerland) atomising humidifier with humidistat controller, and shadecloth on the glasshouse roof maintain between 15 and $28 \mathrm{C}$ for 21 to 28 days. The humidifier with a room capacity of $143 \mathrm{~m}^{3}$ maintains an average relative humidity $(\mathrm{RH})$ of $97 \%$ (range of $75 \%$ to $100 \%$ ). Outside the tent, in the vented glasshouse, the $\mathrm{RH}$ averaged $67 \%$ and ranged from $33 \%$ to $97 \%$.

The component costs (Oct. 1991) were (all in U.S. dollars) $15 \mathrm{~m}$ of Fabricon at $\$ 1.50$ / $\mathrm{m}, \$ 22.50$; cutting, hemming, zip and hooks, $\$ 60$; and humidifier with an output of 0.79 literso $\cdot \mathrm{h}^{-1}, \$ 450$; total, $\$ 532.50$. An additional humidifier may be necessary if the tent is extended to $4.8 \mathrm{~m}$ long.

Results of bacterial spot screening have confirmed this high-humidity tent is very effective. This method of screening can save on field costs and expedite release of resistant cultivars (Russell et al., 1991).

\section{Literature Cited}

Russell, D., J. Heaton, and B. Topp. 1991. Bacterial spot disease resistance breeding for Japanese plums. Proc. Fit Conf. Austral. Soc. Hort. Sci., Sydney, Austral. 30 Sept.-3 Oct. 1991.

Topp, B.L. and D.M. Russell. 1989. Breeding early ripening Japanese plums. Austral. Temperate Fruits Rev. Conf. Acta Hort. 240:27-30.

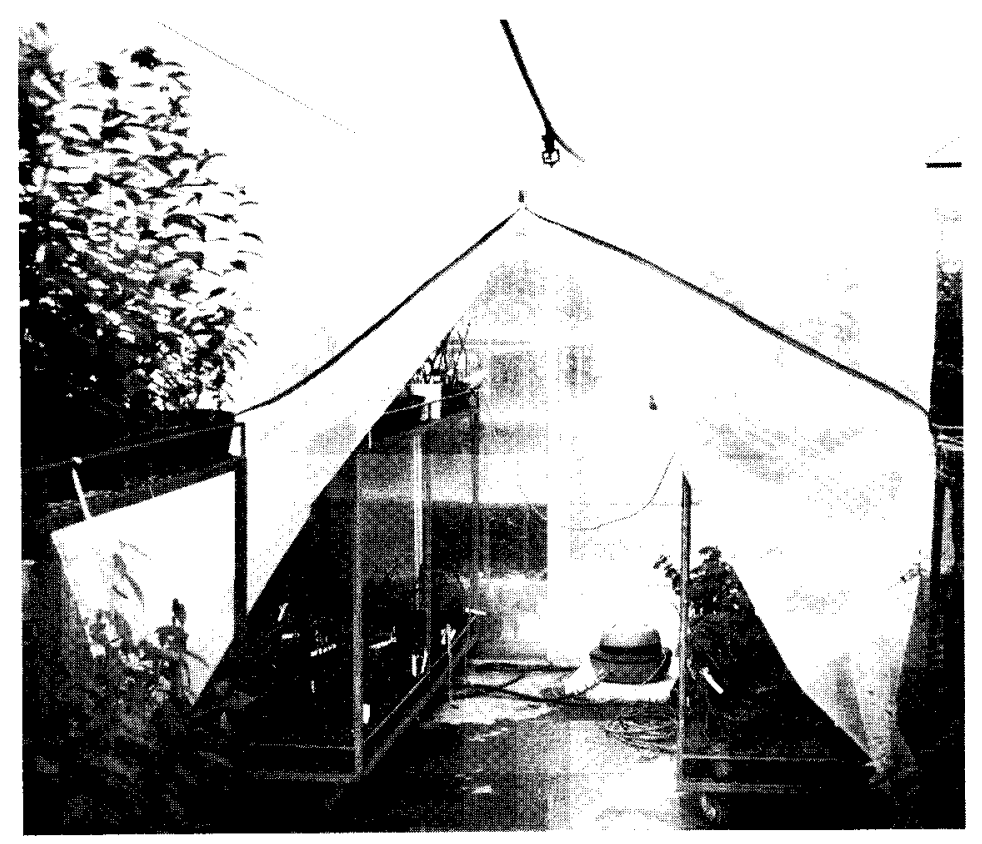

Fig. 1. Suspended plastic curtain with a zippered doorway revealing humidifier and double-layered benches. There is ample room for an inoculation bench to be used in the facility. 